\title{
Implementasi Web Crawling Untuk Pencarian Harga Sparepart Pada PT Asuransi Sinar Mas
}

\author{
Deddy $^{1}$, Evangs Mailoa, S.Kom., M.Cs. ${ }^{2}$ \\ ${ }^{1,2}$ Universitas Kristen Satya Wacana; Jl. Diponegoro No.52-60, Salatiga, Kec. Sidorejo, Kota \\ Salatiga, Jawa Tengah 50711, (0298) 321212 \\ ${ }^{3}$ Jurusan Teknik Informatika, FTI UKSW, Salatiga \\ e-mail: *1deddywiran1@gmail.com, 2evangs.mailoa@uksw.edu,
}

\begin{abstract}
Abstrak
Ketersediaan informasi sparepart kendaraan merupakan salah satu kebutuhan utama dalam proses bisnis yang dijalankan oleh suatu perusahaan asuransi. Salah satu perusahaan asuransi yang membutuhkan ketersediaan informasi tersebut adalah PT. Asuransi Sinar Mas. Informasi sparepart yang dibutuhkan didapat dari website yang tersedia di internet. Namun karena banyaknya informasi sparepart kendaraan yang dibutuhkan dan karena keterbatasan waktu yang ada maka diperlukan sebuah program yang disebut web crawler. Web crawler adalah sebuah program yang melakukan penjelajahan seluruh URL dari website, menelusurinya satu-persatu, kemudian menyimpan semua informasi yang terkandung didalam website tersebut. Web crawler pada penelitianinimenggunakanbahasapemrograman Python dengan framework Scrapy. Hasil dari penelitian ini adalah sebuah aplikasi web crawling yang akan digunakan untuk mengambil data dan harga sparepart mobil Suzuki secara otomatis dari website Suzuki.co.id/eparts yang digunakan memenuhi kebutuhan informasi sparepart yang dibutuhkan oleh PT. AsuransiSinar Mas.
\end{abstract}

Kata kunci-Web Crawling, Python, Scrapy

\begin{abstract}
The availability of vehicle spare parts information is one of the main needs in a business process run by an insurance company. One of the insurance companies that requires the availability of this information is PT. Sinar Mas Insurance. The required spare part information is obtained from the website available on the internet. However, because of the large amount of vehicle spare parts information needed and due to the limited time available, a program called a web crawler is needed. A web crawler is a program that crawls the entire URL of a website, tracks it one by one, then stores all the information contained in the website. The web crawler in this study uses the Python programming language with the Scrapy framework. The result of this research is a web crawling application that will be used to retrieve data and prices for Suzuki car parts automatically from the Suzuki.co.id/eparts website which is used to meet the needs for spare parts information required by PT. Sinar Mas Insurance.
\end{abstract}

Keywords-Web Crawling, Python, Scrapy 


\section{PENDAHULUAN}

Kebiasaan baru dalam masyarakat sekarang adalah mencari informasi melalui internet karena data dan fakta pada internet sangat beragam dan dapat diakses kapan saja [1]. Website merupakan salah satu sumber informasi pada internet yang dapat memenuhi kebutuhan masyarakat akan informasi. Untuk mengumpulkan dan mengunduh informasi pada suatu website dibuatlah sebuah program yang disebut dengan web crawling. Web Crawling adalah suatu program untuk mengunduh seluruh halaman suatu website, web crawling juga bisa digunakan untuk aplikasi pengarsipan website untuk halaman website berskala besar, web crawling akan secara berkala mengumpulkan dan mengarsipkan seluruh website tersebut [2]. Cara kerja web crawling adalah mengekstraksi informasi pada website yang berasal dari sumber daya yang tersedia di web, sumber daya tersebut dapat berupa dokumen atau web service [3].

Salah satu perusahaan yang membutuhkan program web crawling adalah PT. Asuransi Sinar Mas. PT. Asuransi Sinar Mas memiliki berbagai macam bisnis, salah satu bisnisnya adalah asuransi kendaraan bermotor. Dalam proses bisnis asuransi kendaraan bermotor PT. Asuransi Sinar Mas membutuhkan informasi data dan harga sparepart mobil dan salah satunya adalah data dan harga sparepart mobil Suzuki. Informasi data sparepart tersebut dibutuhkan untuk dijadikan acuan dalam melakukan proses pembelian sparepart mobil Suzuki.

Pencarian data dan harga sparepart mobil Suzuki sebelumnya dilakukan secara manual oleh admin melalui website resmi Suzuki yaitu suzuki.co.id/eparts. Namun dengan adanya program web crawling ini proses pencarian harga sparepart dilakukan secara otomatis oleh program dan hasil yang didapat dari program web crawling merupakan seluruh data sparepart yang terdapat website suzuki.co.id/eparts. Dengan adanya program web crawling membuat proses pencarian harga sparepart menjadi lebih cepat dan efisien daripada proses pencarian harga sparepart yang dilakukan secara manual oleh admin melalui website suzuki.co.id/eparts. Selain itu keunggulan web crawling adalah jumlah dan akurasi data dan harga sparepart yang didapat. Karena dengan menggunakan program web crawling ini data sparepart yang didapat lebih banyak dan akurat sehingga data sparepart yang diperoleh dapat diolah lebih lanjut.

Berdasarkan latar belakang masalah tersebut maka dilakukan penelitian yang bertujuan untuk melakukan implementasi web crawling untuk mendapatkan harga sparepart mobil Suzuki pada website resmi Suzuki. Adapun manfaat dari penelitian ini adalah mendapatkan harga sparepart mobil Suzuki yang akan digunakan untuk dijadikan acuan untuk membantu dalam proses bisnis pada PT. Asuransi Sinar Mas.

\section{METODE PENELITIAN}

\subsection{Kajian Pustaka}

\section{1.1Penelitian Terdahulu}

Penelitian pertama yang digunakan sebagai pembanding dalam penelitian ini adalah penelitian yang dilakukan oleh Hanifah \& Nurhasanah yang berjudul "Implementasi Web Crawling Untuk Mengumpulkan Informasi Wisata Kuliner di Bandar Lampung". Penelitian ini bertujuan untuk mengumpulkan informasi mengenai objek-objek wisata kuliner di Bandar Lampung dan menghasilkan informasi objek wisata kuliner yang paling diminati di Bandar Lampung. Hasil dari penilitian ini menghasilkan 129 informasi terkait restoran atau wisata kuliner yang terdapat di Bandar Lampung. Dari 129 informasi tersebut tingkat keakuratan informasi tersebut adalah $71.1 \%$ dan isi informasi tersebut mencakup alamat, kode pos, no telepon, kota, website, rating, dan jumlah reviewer. Pada penelitian ini proses web crawling dibuat menggunakan bahasa pemrograman $\mathrm{R}$ [4]. 
Penelitian yang dilakukan oleh Prasetya yang berjudul "Perbandingan Teknik Web Crawler untuk Mendukung Sistem Pemerolehan Informasi PMB Menggunakan Model Pemerolehan Boolean". Penelitian ini bertujuan membantu siswa dan siswi SMA di kota Yogyakarta untuk mencari informasi mengenai penerimaan mahasiswa baru di website universitas-universitas di Yogyakarta. Informasi yang ingin dicari diantaranya di website universitas terkait adalah penerimaan mahasiswa baru, biaya, dan beasiswa. Hasil yang didapat dari penelitian ini adalah berupa list website universitas-universitas di kota Yogyakarta yang di dalamnya terdapat informasi mengenai penerimaan mahasiswa baru (PMB), biaya, dan beasiswa. Pada penelitian ini proses web crawling dibuat menggunakan framework Apache Nutch dengan database MySQL [5].

Pada penelitian yang dilakukan oleh Hanifah, \& Nurhasanah mengenai implementasi web crawling untuk mengumpulkan informasi wisata kuliner di Bandar Lampung, proses pembuatan web crawling tersebut menggunakan bahasa pemrograman R. Penelitian yang dilakukan Prasetya mengenai implementasi web crawling untuk memperoleh informasi penerimaan mahasiswa baru menggunakan framework Apache Nutch dengan database MySQL. Yang membedakan penelitian ini dengan penelitian sebelumnya adalah pada penelitian ini menggunakan bahasa pemrograman Python dengan framework Scrapy untuk mengimplementasikan program, web crawling pada website suzuki.co.id/eparts.

\section{1.2 Web Crawler}

Web Crawler adalah program yang bekerja dengan metode tertentu dan secara otomatis mengumpulkan semua informasi yang ada dalam suatu website. Web crawler akan mengunjungi setiap URL yang diberikan kepadanya, akan mengunjungi URL tersebut satu per satu. Setiap page URL yang dikunjungi akan diidentifikasi siapakah ada dalam URL tsb di dalamnya terdapat URL yang belum dikunjungi. Jika ada URL yang belum dikunjungi maka akan ditambahkan kedalam list URL yang akan dikunjungi. Siklus mengambil dan menambahkan list URL ini akan terus berlanjut sampai tidak ada lagi URL yang belum dikunjungi. Proses crawling tersebut ini disebut crawl frontier [6].

Dalam proses crawling suatu website akan sangat berkaitan dengan URL. URL (Uniform Resource Locator) adalah sistem pengalamatan yang berisi karakter tertentu berupa angka, huruf, dan simbol yang menuju pada halaman web di jaringan internet. Fungsi URL adalah untuk mengidentifikasi alamat situs web, URL juga berisi informasi alamat situs dimana resource ditempatkan, memindahkan user dari satu halaman ke halaman lain dengan menggunakan media hyperlink. Contoh dari sebuah alamat URL https://www.suzuki.co.id/eparts/aerio-baleno-next-g/engine/figure/17401. Komponen contoh URL tersebut adalah sebagai berikut:

a. https :// adalah tipe internet protokol yang digunakan untuk menyimpan dan mengirim informasi.

b. www. adalah host yang digunakan untuk mengakses situs web.

c. suzuki adalah nama domain.

d. co.id adalah domain khusus yang digunakan perusahaan Indonesia.

e. /eparts/aerio-baleno-next-g/engine/adalah letak direktori yang digunakan untuk mengatur halaman web atau file

f. /figure /17401 adalah file yang ditunjukan oleh URL yang berisi data sparepart pada model sparepartnomor 17401.

Dengan adanya URL mempermudah user dalam memahami alamat dan isi sebuah website yang terdapat pada internet [7]. 


\subsection{Metodologi Penelitian}

Pada penelitian ini menggunakan metode Waterfall. Metode Waterfall merupakan salah satu metode pengembangan perangkat lunak yang ada di dalam model SDLC (Sequencial Development Life Cycle). Sequencial Development Life Cycle adalah proses-proses mengembangkan atau mengubah suatu sistem perangkat lunak dengan menggunakan modelmodel dan metodologi berdasarkan cara-cara yang sudah teruji baik [8]. Adapun tahapan dalam penelitian ini adalah sebagai berikut: (1) tahap Identifikasi Masalah, (2) tahap Perancangan Sistem, (3) tahap Impelementasi Sistem, (4) tahap Pengujian Sistem.

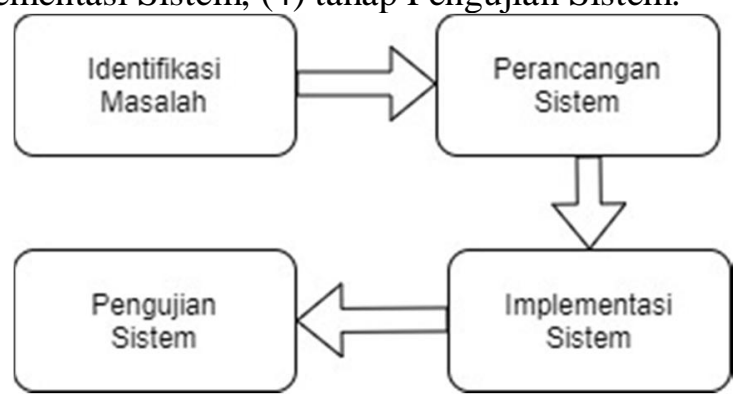

Gambar 1. Tahapan Penelitian

Gambar 1 merupakan tahapan jalannya penelitian yang dijelaskan sebagai berikut. Langkah 1: Identifikasi masalah pada penelitian ini dimulai dari mengidentifikasi masalah yang dihadapi team procurement dalam proses mencari harga sparepart. Proses mengidentifikasi masalah ini dilakukan dengan cara berdiskusi dengan Ibu Herlin Zebua (Kadiv team procurement). Setelah proses berdiskusi dengan Ibu Herlin Zebua maka ditemukan kendala bahwa team procurement mengalami kesulitan dalam proses mencari harga sparepart mobil karena database sparepart yang ada pada team procurement berisi data dan harga sparepart yang belum di update sehingga data dan harga sparepart tersebut tidak mengikuti data dan harga terbaru sparepart resmi dari produsen mobil yang ada. Sehingga team procurement harus melakukan proses pencarian harga sparepart secara manual melalui website-website sparepart resmi yang ada.

Langkah 2: Perancangan sistem pada penelitian ini dimulai dengan merancangkan aplikasi apa yang akan dibuat untuk menjawab permasalahan yang dihadapi oleh team procurement. Perancangan sistem pada penilitian ini dilakukan dengan perancangan UML diagram yang meliputi use case diagram dan activity diagram. Tujuan dari perancangan sistem ini adalah untuk mendapatkan gambaran umum sistem yang akan dibangun.

Langkah 3: Implementasi sistem pada penelitian ini dilakukan dengan cara menterjemahkan design program yang telah dibuat dirancang sebelumnya kedalam bahasa pemograman Python dan menggunakan framework Scrapy untuk proses web crawling. Output dari sistem ini adalah data sparepart mobil Suzuki yang akan digunakan untuk dijadikan acuan oleh team sparepart dalam membandingkan harga pada website resmi dengan harga yang ditawarkan oleh supplier.

Langkah 4: Pengujian sistem pada penelitian ini dilakukan metode Black Box. Black box testing merupakan metode pengujian program yang lebih berfokus pada tampilan antarmuka dan fungsional suatu program tanpa mengetahui apa yang terjadi pada coding program tersebut [9]. Black box testing yang diterapkan pada penelitian ini adalah menguji apakah data sparepart yang didapat dari hasil crawling pada website suzuki.co.id/eparts sama dengan data sparepart pada website suzuki.co.id/eparts.

Gambar 2 merupakan tampilan use case diagram dan activity diagram pada penelitian ini. 


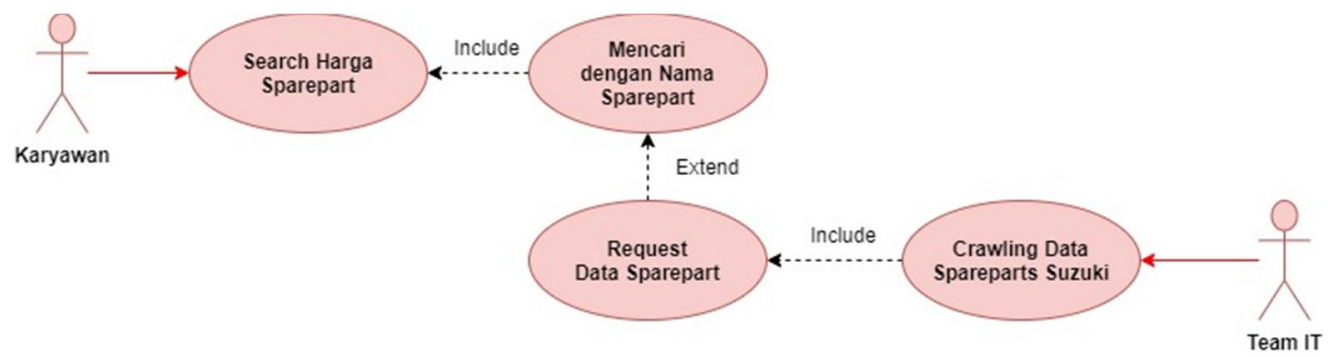

Gambar 2. Use Case Diagram

Gambar 2 merupakan use case diagram yang digunakan pada penelitian ini. Pada diagram tersebut terdapat 2 aktor yaitu karyawan yang berperan sebagai aktor yang akan melakukan proses pencarian harga sparepart dan Team IT yang berperan sebagai aktor yang akan melakukan proses web crawling pada web suzuki.co.id/eparts dan melakukan proses penambahan data sparepart yang tidak ada pada database sparepart team procurement. Dalam proses mencari harga sparepart pada, team procurement selalu menggunakan nama dari sparepart yang ingin dicari harganya. Setelah melakukan proses pencarian dan ternyata sparepart tersebut tidak ditemukan maka team procurement melakukan request data sparepart tersebut kepada team IT untuk ditambahkan kedalam database sparepart team procurement.

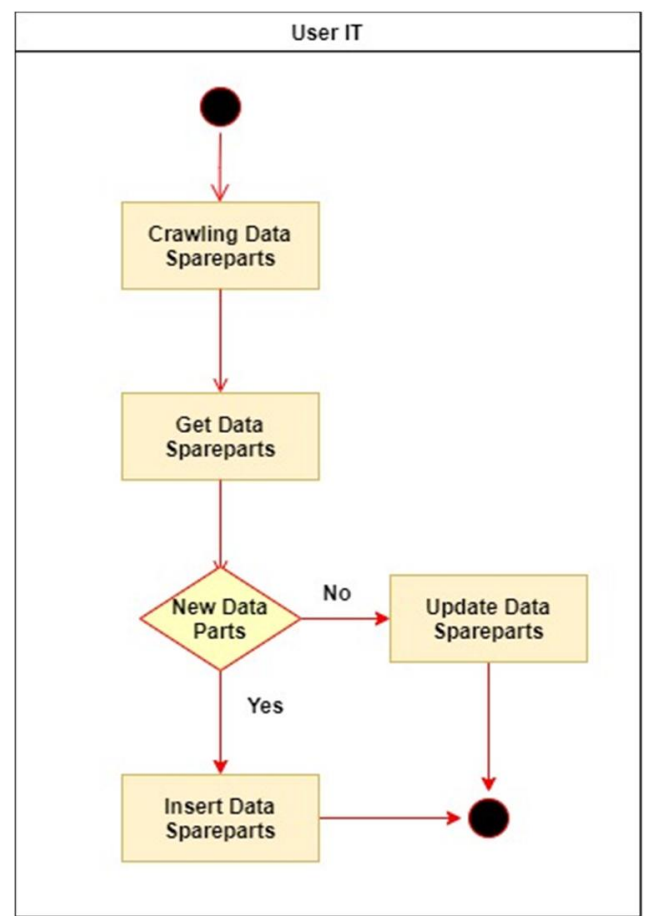

Gambar 3. Activity Diagram Proses Crawling Data Sparepart

Gambar 3 menunjukan activity diagram untuk proses crawling data sparepart. Pertama, user IT akan melakukan proses crawling data sparepart pada website Suzuki E-Parts. Setelah proses crawling selesai dan mendapat data sparepart, user IT akan mengecek apakah data sparepart yang di dapat tersebut merupakan data sparepart yang baru, jika merupakan data baru maka data sparepart tersebut di tambahkan kedalam master data sparepart Suzuki dan jika tidak maka hanya dilakukan proses update data sparepart pada master data sparepart Suzuki berdasarkan data yang didapatkan dari proses crawling pada website Suzuki E-Parts. 


\section{HASIL DAN PEMBAHASAN}

Proses pembuatan kode program web crawling pada penelitian ini dibuat menggunakan Python dengan bantuan framework Scrapy. Python merupakan Bahasa pemrograman berorientasi objek yang dinamis dan dapat digunakan untuk mengembangkan berbagai jenis perangkat lunak Python dilengkapi dengan library standar yang luas dan dapat dimanfaatkan dalam proses web crawling [10]. Scrapy adalah sebuah web framework yang kuat untuk mengambil data dari berbagai sumber. Scrapy adalah salah satu framework Python yang memiliki fungsi utama dalam proses ekstraksi data dari halaman web dengan menyertakan URL dari halaman web yang akan di ekstrak. Pada scrapy terdapat scheduler yang mengatur bagaimana crawling nanti berjalan, didalam scrapy juga terdapat banyak fitur-fitur yang dapat mempermudah proses web crawling diantaranya ada Spider yang akan melakukan scraping kelaman situs tertentu [11]. Proses crawling yang dilakukan pada penilitian adalah sebagai berikut.

Proses pertama yang dilakukan pada crawling data ini adalah mengambil data untuk semua model kendaraan Suzuki yang terdaftar pada website suzuki.co.id/eparts. Model kendaraan yang terdapat pada website suzuki.co.id/eparts adalah seperti pada Gambar 4.

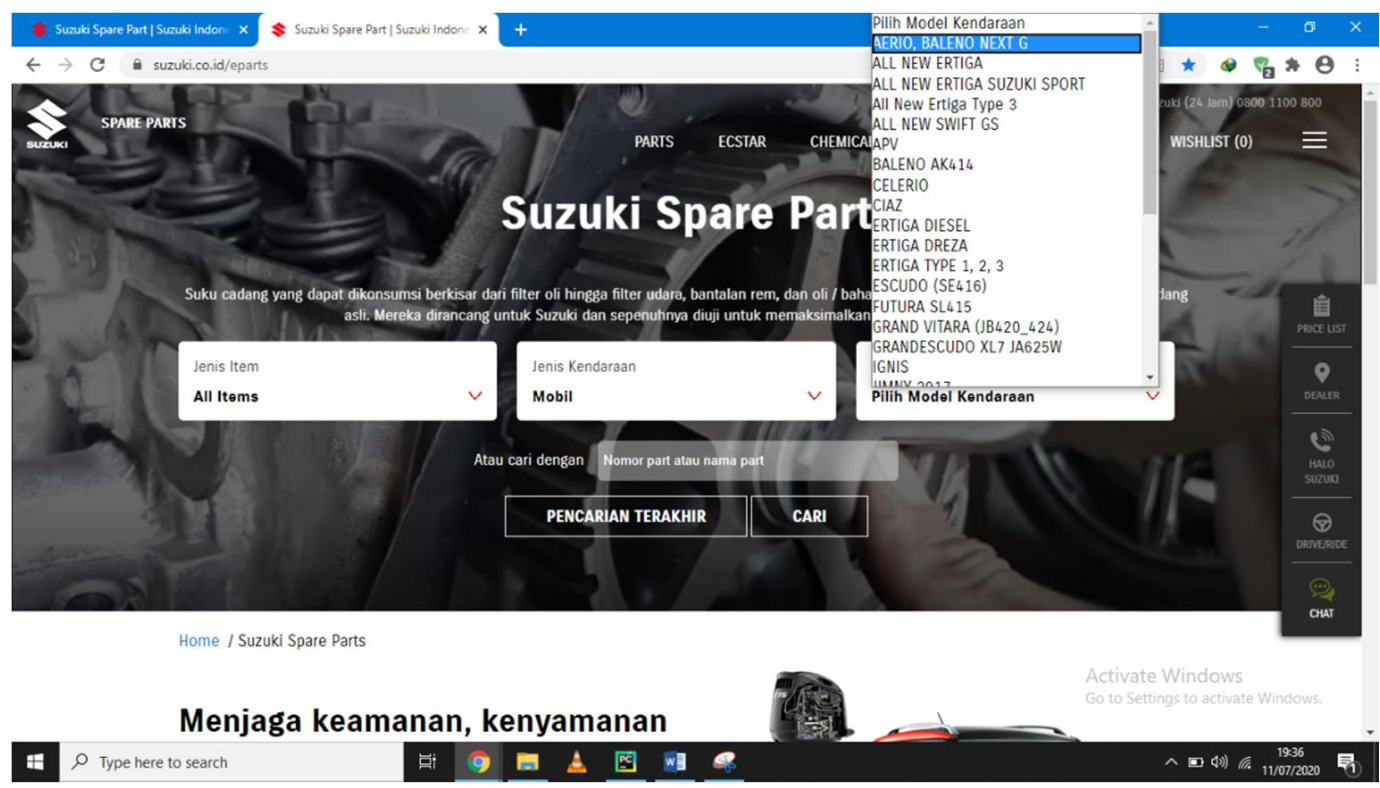

Gambar 4. Model Kendaraan pada Website Suzuki.co.id/eparts

Gambar 4 merupakan salah satu contoh hasil link nama model kendaraan dan nama model kendaraan Suzuki yang berhasil di crawling dari website suzuki.co.id/eparts 


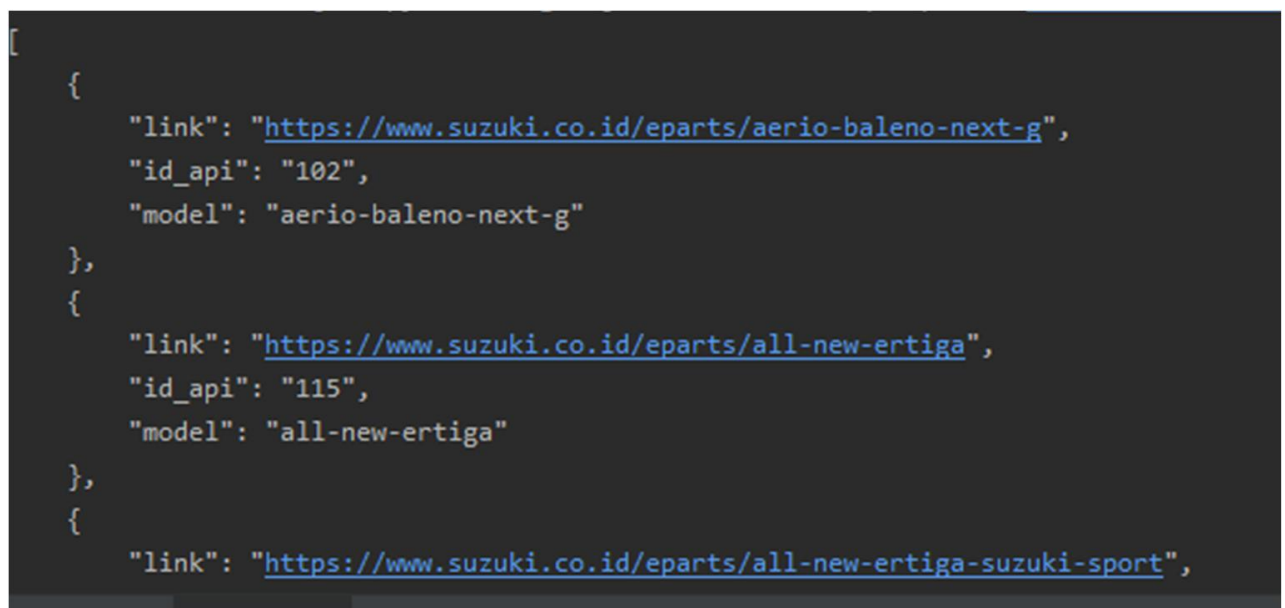

Gambar 5. Model Kendaraan yang Berhasil di Crawling dari Website suzuki.co.id/eparts

Pada Gambar 5. merupakan salah satu contoh hasil link model kendaraan dan nama model kendaraan Suzuki yang berhasil di crawling dari website suzuki.co.id/eparts. Link model kendaraan dan nama model kendaraan Suzuki tersebut adalah aerio baleno next $g$ dan all new ertiga.

Proses selanjutnya adalah crawling link bagian kendaraan atau section yang ada pada website suzuki.co.id/eparts. Pada website suzuki.co.id/epart sini data sparepart dikelompokan menjadi perbagian kendaraan atau persection dan section tersebut adalah Preview, Engine, Transmission, Electrical, Suspension, dan Body. Section kendaraan yang terdapat pada website suzuki.co.id/eparts adalah seperti pada Gambar 6.

Home / E-Parts / AERIO, BALENO NEXT G / Preview

\section{AERIO, BALENO NEXT G}

Preview engine transmission electrical suspension body

Gambar 6. Section Kendaraan pada Website suzuki.co.id/eparts

Section-section tersebut memiliki link yang berbeda-beda sehingga harus diproses satu per satu dalam crawling datanya pada tiap bagian. Pada proses ini juga proses link-link dari bagian kendaraan tersebut diambil. Berikut merupakan hasil section kendaraan Suzuki yang berhasil di crawling dari website suzuki.co.id/eparts 


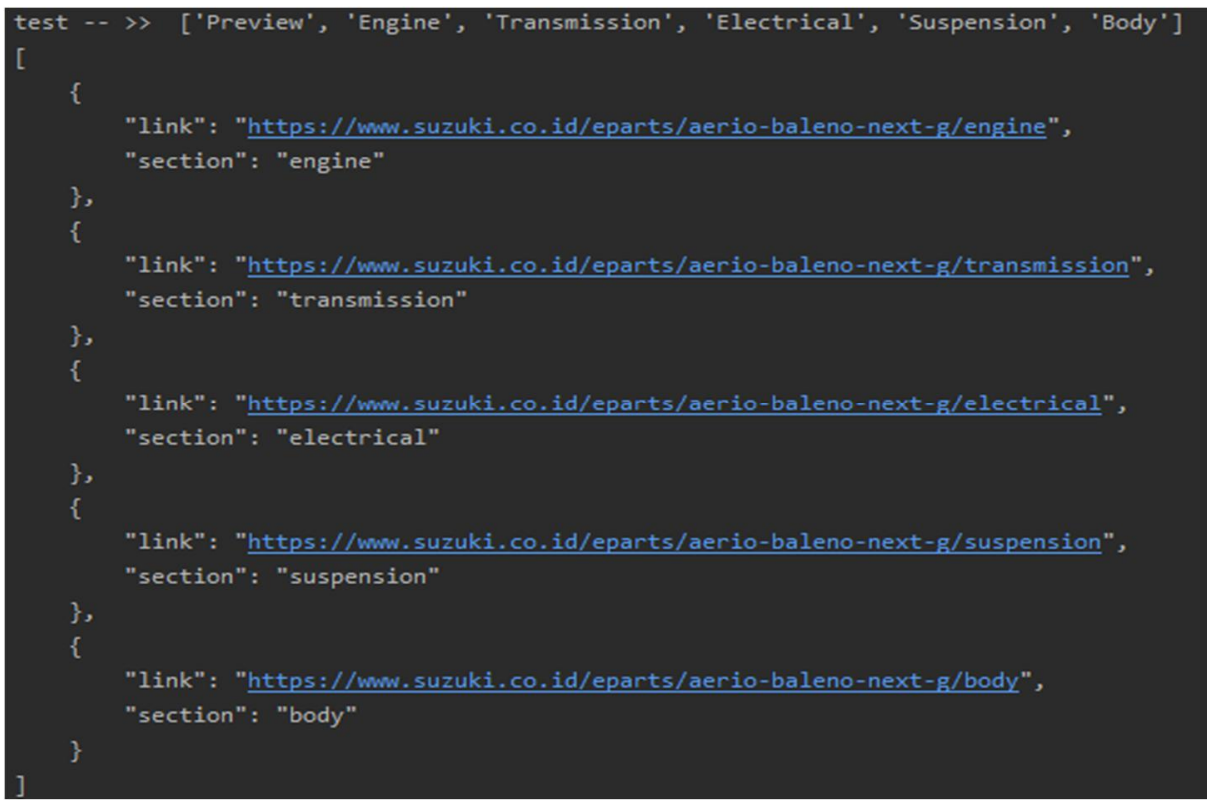

Gambar 7. Hasil Section Kendaraan Suzuki yang Berhasil di Crawling dari Website suzuki.co.id/eparts

Pada Gambar 7. Merupakan hasil section kendaraan yang berhasil di crawling dari website suzuki.co.id/eparts. Dari 6 section yang ada hanya pada 5 section kendaraan yang terdapat data sparepart di dalamnya yaitu pada section engine, transmission, electrical, suspension dan body.

Setelah proses mengambil link pada section engine, transmission, electrical, suspension, body selesai dilakukan proses selanjutnya adalah mengambil link untuk model sparepart yang terdapat pada section engine, transmission, electrical, suspension dan body. Model sparepart yang terdapat pada website suzuki.co.id/eparts adalah seperti pada Gambar 8.

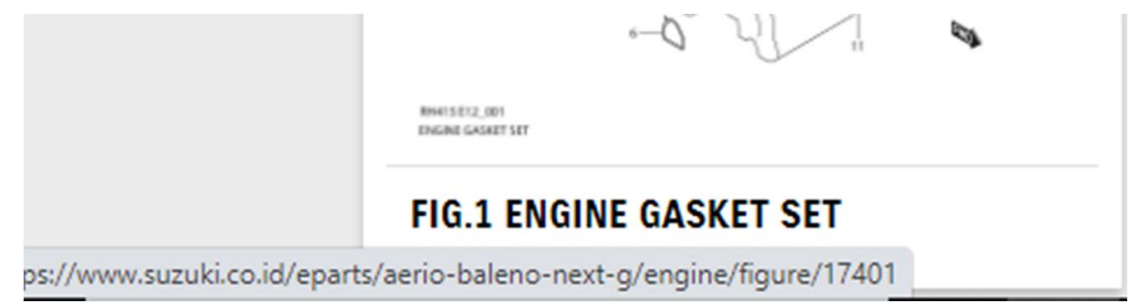

Gambar 8. Section Kendaraan pada Website suzuki.co.id/eparts

Model-model sparepart tersebut memiliki link yang berbeda-beda sehingga harus diproses satu persatu dalam crawling datanya pada tiap bagian. Pada proses ini juga proses linklink dari tiap model sparepart yang ada pada tiap section diambil. Berikut merupakan hasil link model kendaraan Suzuki pada section engine yang berhasil di crawling dari website suzuki.co.id/eparts. 


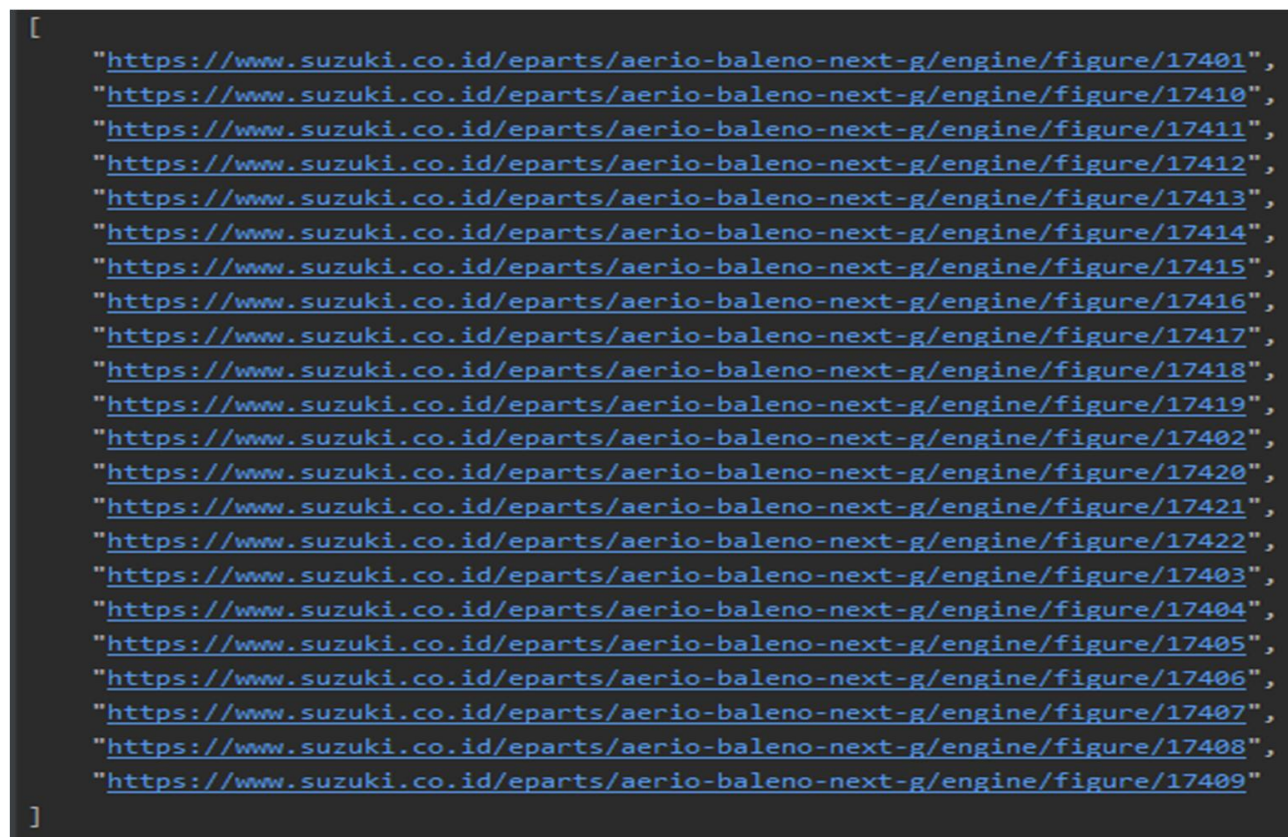

Gambar 9. Link Model Sparepart pada Section Engine yang Berhasil di Crawling dari Website suzuki.co.id/eparts

Pada Gambar 9. merupakan link model sparepart pada section Engine yang berhasil di crawling dari website suzuki.co.id/eparts. Model-model sparepart yang terdapat pada section engine adalah FIG.1 Engine Gasket Set, FIG.10 Intake Manifold, FIG.12 Air Cleaner, FIG.13 Exhaust Manifold, dll.

Proses selanjutnya adalah mengambil semua data sparepart berada pada model sparepart yang terdapat pada tiap section kendaraan. Data sparepart yang diambil dari website suzuki.co.id/eparts ini antara lain adalah data: no, part, subtitusi, deskripsi, jumlah, harga, id part, model, dan section. Berikut merupakan salah satu contoh data sparepart yang terdapat pada model sparepart FIG.1 Engine Gasket Set

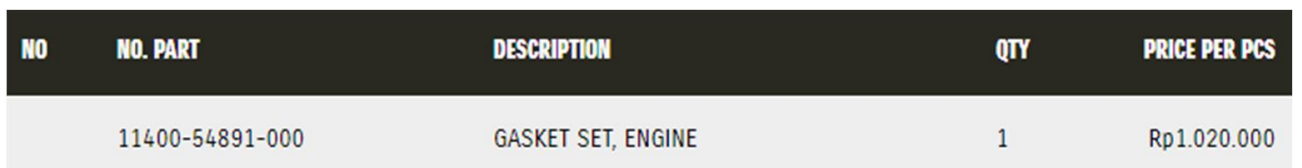

Gambar 10. Contoh Data Sparepart pada Model Sparepart FIG.1 Engine Gasket Set

Salah satu contoh data sparepart yang terdapat pada model sparepart FIG.1 Engine Gasket Set dan yang berhasil diambil dari website suzuki.co.id/eparts oleh program ini adalah seperti pada Gambar 11. 


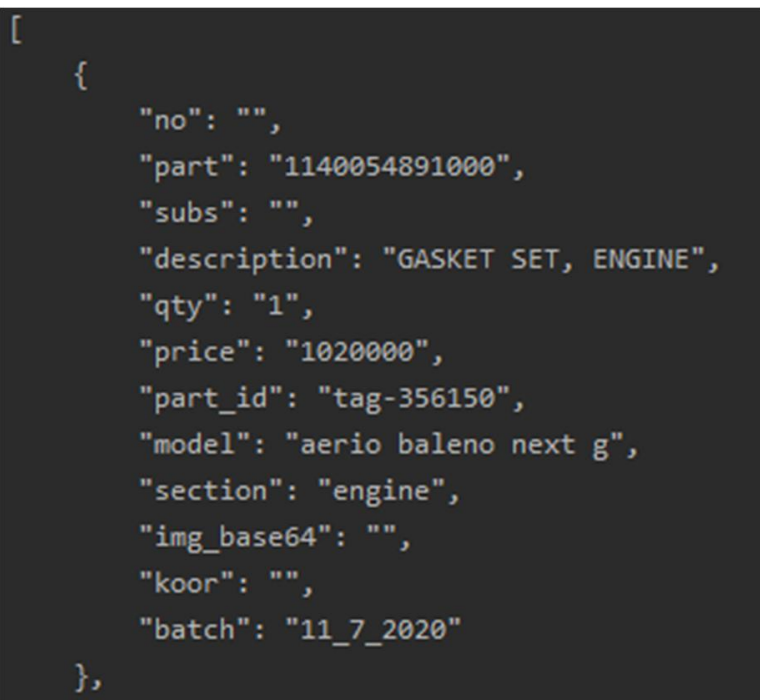

Gambar 11. Contoh Hasil Data Sparepart yang Berhasil di Crawling

Pada Gambar 11. Merupakan contoh hasil data sparepart yang berhasil di crawling pada section Engine pada model sparepart FIG.1 Engine Gasket Set dari website suzuki.co.id/eparts. Data sparepart tersebut adalah Gasket Set, Engine. Data sparepart yang di crawl dari website suzuki.co.id/eparts terdiri dari No, Part, Subtitusi, Deskripsi Sparepart, Jumlah Sparepart, Harga Sparepart, ID Part, Model Sparepart dan Section Sparepart.Tabel 1 merupakan contoh data sparepart dari hasil web crawling yang dilakukan pada website suzuki.co.id/eparts.

Tabel 1. Contoh Hasil Web Crawling Website suzuki.co.id/eparts

\begin{tabular}{|c|c|c|l|c|c|c|c|c|}
\hline No & Part & Subtitusi & Deskripsi & Jumlah & Harga & ID Part & Model & Section \\
\hline 1 & 1414069 G00000 & - & $\begin{array}{l}\text { Gasket, } \\
\text { Exhaust Manifold }\end{array}$ & 1 & Rp. 111.000 & $\begin{array}{c}\text { tag- } \\
356157\end{array}$ & $\begin{array}{c}\text { aeriobaleno } \\
\text { next g }\end{array}$ & Engine \\
\hline 2 & 1655969 GE0000 & & $\begin{array}{l}\text { Gasket, } \\
\text { Oil Control Valve' }\end{array}$ & 1 & Rp. 32.000 & $\begin{array}{c}\text { tag- } \\
356158\end{array}$ & $\begin{array}{c}\text { aeriobaleno } \\
\text { next g }\end{array}$ & Engine \\
\hline 3 & $1758254 \mathrm{D} 00000$ & - & $\begin{array}{l}\text { O Ring, } \\
\text { Water Outlet Cap } \\
\text { No.1 }\end{array}$ & 1 & Rp. 20.500 & $\begin{array}{c}\text { tag- } \\
356159\end{array}$ & $\begin{array}{c}\text { aeriobaleno } \\
\text { next g }\end{array}$ & Engine \\
\hline 4 & 0928028008000 & $09280 \mathrm{~B} 28008 \mathrm{~N} 000$ & $\begin{array}{l}\text { O Ring, } \\
\text { Thrm Outlet Pipe }\end{array}$ & 3 & Rp. 15.000 & $\begin{array}{c}\text { tag- } \\
356162\end{array}$ & $\begin{array}{c}\text { aeriobaleno } \\
\text { next g }\end{array}$ & Engine \\
\hline 5 & 0928062003000 & - & $\begin{array}{l}\text { O Ring, } \\
\text { Oil Adapter Case' }\end{array}$ & 1 & Rp. 34.500 & $\begin{array}{c}\text { tag- } \\
356163\end{array}$ & $\begin{array}{c}\text { aeriobaleno } \\
\text { next g }\end{array}$ & Engine \\
\hline
\end{tabular}

Pengujian sistem pada aplikasi ini dilakukan menggunakan metode black box testing. Black box testing merupakan metode pengujian program yang lebih berfokus pada tampilan antarmuka dan fungsional suatu program tanpa mengetahu siapa yang terjadi pada coding program tersebut [8]. Black box testing yang diterapkan pada penelitian ini adalah menguji apakah data sparepart yang didapat dari hasil web crawling pada website suzuki.co.id/eparts sama dengan data sparepart pada website suzuki.co.id/eparts. Berikut merupakan contoh data sparepart yang ada pada website suzuki.co.id/eparts. 


\begin{tabular}{|llll|}
\hline NO NO. PART & DESCRIPTION & OTY & PRICE PER PCS \\
\hline $11400-54891-000$ & GASKET SET, ENGINE & 1 & Rp1.020.000 \\
\hline $11400-69840-000$ & GASKET SET, ENGINE & 1 & Rp 1.034 .500 \\
\hline
\end{tabular}

Gambar 12. Contoh Sata Sparepart yang Ada pada Website suzuki.co.id/eparts

Data sparepart pada Gambar 12 merupakan contoh data sparepart terdapat pada website suzuki.co.id/eparts. Pada Gambar 13 merupakan contoh data sparepart yang berhasil di crawling dari website suzuki.co.id/eparts.

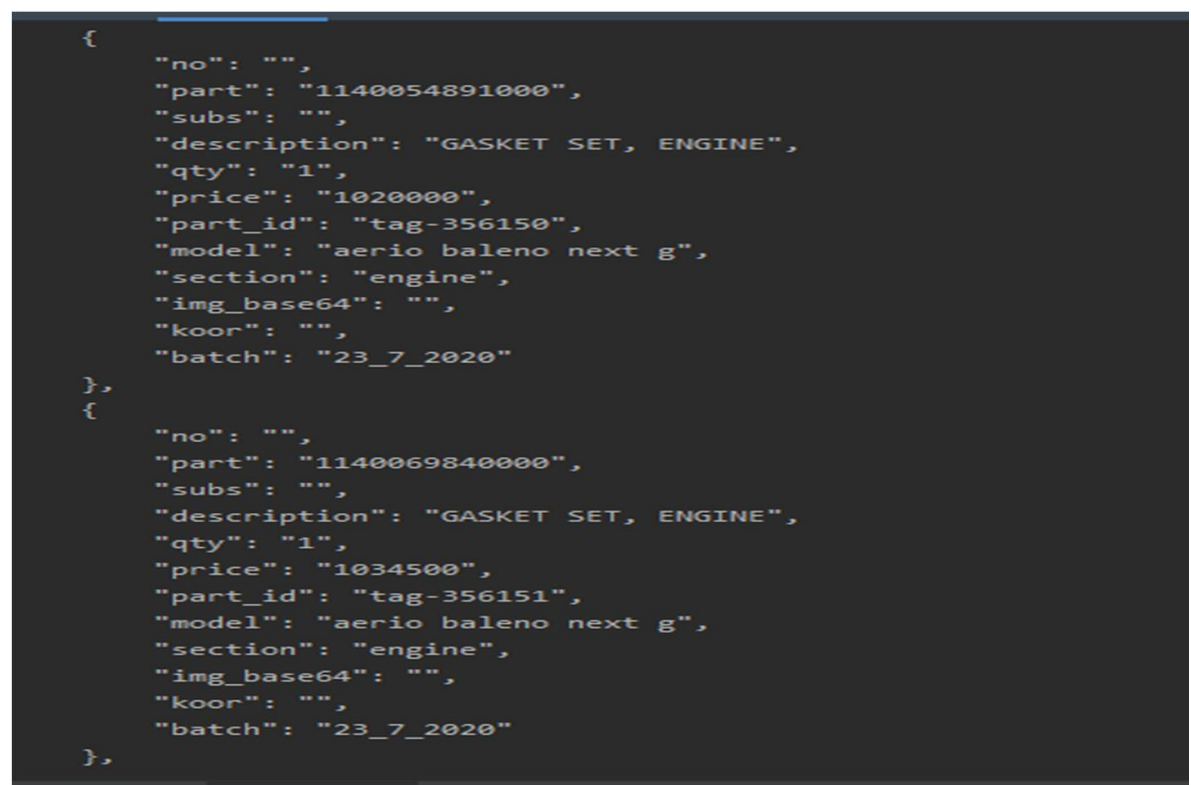

Gambar 13. Contoh Data Sparepart Hasil Crawling dari Website suzuki.co.id/eparts

Terlihat bahwa dari Gambar 12 dan Gambar 13 hasil dari website Suzuki.co.id/eparts dan dari aplikasi yang dibangun, memiliki hasil sama. Dengan demikian, pengujian ini dapat dijadikan sebagai tolak ukur bahwa aplikasi yang dibangun bekerja dengan baik dan benar.

\section{KESIMPULAN}

Pada penelitian ini dilakukan proses pembuatan program web crawling yang akan digunakan untuk mengambil data sparepart secara otomatis dari website suzuki.co.id/eparts. Proses web crawling sparepart pada penelitian ini sudah berhasil dilakukan, dan data sparepart yang didapat pun sudah sesuai dan dapat digunakan oleh team procurement untuk dijadikan acuan dalam proses bisnis. Dengan penelitian ini dapat disimpulkan bahwa web crawling merupakan salah satu metode yang bisa digunakan untuk mengumpulkan dan mengambil informasi dari suatu website. Website yang dapat dijadikan obyek web crawling juga beragam contohnya seperti website suzuki.co.id/eparts yang merupakan website yang berisi informasi mengenai penjualan sparepart mobil Suzuki secara online yang dijadikan website acuan pada penelitian ini. 


\section{SARAN}

Adapun saran yang dapat diberikan oleh penulis berdasarkan kesimpulan yang didapatkan adalah:

1. Perusahaan perlu terus mengembangkan inovasi di sektor teknologi informasi seperti menggunakan program crawling ini untuk mendukung proses bisnis yang ada.

2. Perusahaan diharapkan terus mengembangkan dan memanfaatkan program web crawling ini untuk mencari informasi pada website-website lain selain mencari data sparepart pada website suzuki.co.id/eparts.

\section{UCAPAN TERIMA KASIH}

Penulis mengucapkan terima kasih kepada Tuhan Yang Maha Esa karena atas penyertaan-Nya sehingga penulis dapat menyelesaikan jurnal ini. Penulis juga mengucapkan terima kasih kepada keluarga dan teman-teman terdekat yang sudah memberikan dukungan kepada penulis untuk menyelesaikan jurnal ini.

\section{DAFTAR PUSTAKA}

[1] I. P. Sonya, 2016, "Analisis Web Scraping Untuk Data Bencana Alam Dengan Menggunakan Teknik Breadth-First," Vol. 21, No. 3.

[2] R. T. Shita, 2016, "Implementasi Algoritma Bfs ( Breadth-First Search ) pada Aplikasi Web Crawler," Vol. 8, No. 2, pp. 127-132.

[3] A. Overview, K. D. Points, W. Characteristics, C. Crawling, S. Crawling, and E. L. Implementation, 2010, "By Christopher Olston and Marc Najork," Vol. 4, No. 3, pp. $175-246$.

[4] R. Hanifah, I. S. Nurhasanah, P. Studi, T. Informatika, and B. Lampung, 2018, "Implementasi Web Crawling Untuk Mengumpulkan Informasi Wisata Kuliner di Bandar Lampung," Vol. 5, No. 5.

[5] L. A. B. Prasetya, 2018, “ Perbandingan Teknik Web Crawler Untuk Mendukung Sistem Pemerolehan Informasi PMB Menggunakan Model Pemerolehan Boolean” No. 135314094.

[6] Y. Patil, S. Patil, C. Science, and C. Science, 2016, "Review of Web Crawlers with Specification and," Vol. 5, No. 1, pp. 220-223.

[7] A. Halim, R. D. Nyoto, and N. Safriadi, 2017, "Perancangan Aplikasi Web Crawler untuk Menghasilkan Dokumen Teks pada Domain Tertentu," Vol. 5, No. 2, pp. 3-6.

[8] Y. Firmansyah, 2018.,"Penerapan Metode SDLC Waterfall Dalam Pembuatan Sistem Informasi Akademik Berbasis Web Studi Kasus Pondok Pesantren Al-Habi Sholeh Kabupaten Kubu Raya, Kalimantan Barat," Vol. 4, No. 1. 
[9] L. B. Ilmawan, 2018, "Membangun Web Crawler Berbasis Web Service Untuk Data Crawling pada Website Google Play Store," Vol. 10, pp. 215-224.

[10] I. Ramadhan and H. Sastramihardja, 2018, "Pemanfaatan Web Crawler Dalam Mengumpulkan Informasi Melalui Internet," pp. 8-9.

[11] E. H. Fernando, H. Sagala, A. E. Budiman, I. N. Husada, and H. Toba, 2019, “Ekstraksi dan Analisis Produk di Marketplace Secara Otomatis Dengan Memanfaatkan Teknologi Web Crawling," Vol. 5, pp. 350-359. 